\title{
Landscape function analysis as a base of landscape visions
}

\author{
Krisztina FILEPNÉ KOVÁCS, 'István VALÁNSZKI, Ágnes SALLAY, \\ Sándor JOMBACH, Zsuzsanna MIKHÁZI, László KOLLÁNYI \\ Corvinus University of Budapest, \\ Department of Landscape Planning and Regional Development \\ e-mail: krisztina.kovacs@uni-corvinus.hu (*corresponding author); \\ istvan.valanszki@uni-corvinus.hu; agnes.sallay@uni-corvinus.hu; \\ sandor.jombach@uni-corvinus.hu; zsuzsanna.mikhazi@uni-corvinus.hu
}

Manuscript received April 22, 2015; revised May 24, 2015; accepted June 25, 2015

\begin{abstract}
An essential condition for the success of rural areas is the harmonious enforcement of ecologic, economic, and other educational, cultural, aesthetic goods/ services of landscape, diversity of landscape functions. Landscape function analysis is a useful tool for the complex evaluation of rural regions. Using statistic and spatial data, we explored the landscape resources, potentials, and limitations of two pilot regions. But what about the future? Based on the landscape function analysis, we have defined special types of regions/landscape visions according to the long-term ability to retain population by the comparison of economic, production, and habitat value of the landscape.
\end{abstract}

Keywords: landscape scenario, population retention capacity, micro-regions of Gönc, Csorna

\section{Introduction}

There is always more attention paid to rural development and rural landscapes. In our study, we apply landscape function analysis using complex landscape indices to explore the potentials and limits of the landscape. Furthermore, based on the landscape function analysis, we formulated special landscape types reflecting the population retention capacity in the long run.

Nowadays, the terms of ecosystem services and landscape functions are frequently used terminologies within the scientific community. In our study, we prefer the use of landscape functions because it has originated principally from 
landscape ecology and planning $[1,2]$. Furthermore, this concept as an integrative framework integrates natural, economic, social sciences and policy sectors. Landscape services are often defined as "the capacity of the landscape to provide goods and services that satisfy human needs, directly or indirectly" [3].

The term of ecosystem services is rooted in the field of ecology and was originally designed for the assessment of (semi-)natural ecosystems [4]. There are a number of options to group assets offered by nature $[4,5,6,7]$. There is a consensus about four groups of services: provisioning services (food, timber, etc.), regulating services (climate control, water purification, etc.), supporting (soil formation, nutrient cycling) and information services (recreation, education, etc.). Finally, de Groot distinguishes carrier functions, which include cultivation, habitation, and transportation [6].

The term of landscape functions has been developed parallel with the term of ecosystem services in other scientific fields. Bastian (1997) grouped landscape functions according to the three pillars of sustainability, as production (economic), anthropocentric (society), and regulatory (ecological) functions [8].

In rural regions, people still live from the goods of the landscape (agriculture, tourism) or choose rural settlements for living because of the quality of the environment. Therefore, in rural regions for sustainable development, it is extremely important to analyse the level of landscape functions. As pilot areas, we have two rural regions. According to the classification of the OECD and the EU, both of them belong to predominantly rural areas, where more than $50 \%$ of the area's population lives in (rural) communities, where the density of population is under 120 inhabitants $/ \mathrm{km}^{2}$ [9].

The landscape function analysis is the first step in our research project to detect differences of population retention capacity between different types of landscapes. Landscape function analysis is an appropriate tool to explore landscape resources, potentials, and limitations of the present state in rural regions and related landscapes. For rural development, it is an extremely important question whether we are capable to maintain sustainable development in the long run. In the population retention capacity of rural regions, besides the maintenance of the ecologic values, it is inevitable to ensure and maintain a proper, competitive income level. Agriculture and food industry are still a crucial pillar of the economy and employment of rural regions. Furthermore, in a major part of rural regions, villages become especially residential areas from where people commute to the central cities. As an example, we used the multidimensional model for the assessment of the ecologic stability of landscapes, elaborated by Antonio GomezSal and his fellow researchers [10]. We elaborated characteristic landscape models/scenarios describing the population retention capacity based on landscape function analysis. For our research, we have formulated the following objectives: 
- To compare the landscape functions within and in between the pilot areas;

- To create a general scenario model based on the landscape functions;

- To identify these scenarios within the pilot areas;

- To compare the scenarios between the pilot areas and to identify the reasons of differences and similarities.

\section{Materials and methods}

As the first step of our research, based on the concept of landscape functions, we elaborated complex landscape indicators to compare the level of different landscape services and explore the relation between the landscape use and the economic situation of the analysed regions. For the assessment of landscape functions, we used a wide range of complex indicators (Table 1).

Table 1. The structure of the indicator system

\begin{tabular}{|c|c|c|}
\hline \multicolumn{3}{|c|}{ Used indicators of the research } \\
\hline $\begin{array}{l}\text { Group of } \\
\text { indicators }\end{array}$ & Indicators & Database \\
\hline \multirow{4}{*}{ Ecological } & Environmental integrity & Matrix of Koshke based on Corine land cover [11] \\
\hline & $\begin{array}{l}\text { Protected areas of national } \\
\text { importance }\end{array}$ & Proportion of protected areas of national importance \\
\hline & $\begin{array}{l}\text { Protected areas of international } \\
\text { importance }\end{array}$ & $\begin{array}{l}\text { Proportion of Natura 2000, Ramsar sites, Biosphere } \\
\text { reserves }\end{array}$ \\
\hline & National ecological network & Proportion of national ecological network \\
\hline \multirow{2}{*}{$\begin{array}{l}\text { Landscape } \\
\text { aesthetic }\end{array}$} & Naturalness & Proportion of extensive land use forms \\
\hline & Diversity & Shannon-diversity index [12] \\
\hline \multirow{4}{*}{ Production } & Arable land potential & Proportion of arable land indicating fertility \\
\hline & Vine and fruit production potential & Proportion of vineyards and horticulture \\
\hline & Livestock & Number of livestock \\
\hline & Forestry potential & Proportion of forest areas \\
\hline Economic & Economic & Total domestic income per taxpayers and ratio of tax \\
\hline
\end{tabular}

The used landscape indicators mostly cover all types of landscape services $[13,14$, $15,16,17]$. We used the data of the Hungarian Central Statistical Office and other types of databases (Hungarian Spatial Planning and Development Information System - TEIR; database of national monuments, database of landscape values TÉKA; Hungarian nature and environmental protection databases - TIR) for the evaluation of the level of the landscape services and the characterization of settlements and sub-regions.

We aggregated the spatial data on settlement level and harmonized them into a common dimension. The values $(32+34)$ of all settlements of both pilot regions 
were ranged one after the other. Then the values were divided on a scale from 1 to 10. Therefore, we were able to assess not just the situation of settlements in the pilot area but between the pilot regions in general as well.

The landscape function analysis describes the present state of the pilot regions. We explored the population retention capacity of the landscape following the method of Antonio Gomes-Sal and his fellow researchers. We analysed the relation between the economic, ecologic, and production values and elaborated seven basic landscape types (Table 2).

Table 2. Relation between economic, ecologic, and agricultural production dimensions and the population retention capacity of the landscape (based on the model of Gomes-Sal [10])

\begin{tabular}{|c|c|c|c|c|c|}
\hline $\begin{array}{l}\text { Economic } \\
\text { value }\end{array}$ & $\begin{array}{l}\text { Production } \\
\text { value }\end{array}$ & $\begin{array}{l}\text { Ecological } \\
\text { value }\end{array}$ & $\begin{array}{l}\text { Landscape } \\
\text { scenery/Aes } \\
\text { thetic value } \\
\end{array}$ & Landscape type & $\begin{array}{l}\text { Population } \\
\text { retention } \\
\text { capacity } \\
\end{array}$ \\
\hline Low & Low & High & High & $\begin{array}{l}\text { Landscape of traditional, } \\
\text { environmentally friendly, } \\
\text { agricultural production of low } \\
\text { intensity }\end{array}$ & $\begin{array}{l}\text { Low because of } \\
\text { the low } \\
\text { profitability }\end{array}$ \\
\hline Medium & Medium & High & High & $\begin{array}{l}\text { Environmentally friendly, labour } \\
\text { intensive production of high added } \\
\text { value with varied crop structure } \\
\text { "Multifunctional cultural } \\
\text { landscape" }\end{array}$ & $\begin{array}{l}\text { Strong ability to } \\
\text { retain long-term } \\
\text { population }\end{array}$ \\
\hline Low & High & Low & $\begin{array}{c}\text { Low, } \\
\text { Impoverishi } \\
\text { ng landscape }\end{array}$ & $\begin{array}{l}\text { Intensive (industrial) agricultural } \\
\text { landscape }\end{array}$ & $\begin{array}{l}\text { Low because of } \\
\text { the low } \\
\text { profitability and } \\
\text { low need for } \\
\text { labour }\end{array}$ \\
\hline Medium & Low & High & High & $\begin{array}{l}\text { Rich in natural and cultural values, } \\
\text { agricultural subsidies, tourism } \\
\text { "Naturpark" }\end{array}$ & $\begin{array}{l}\text { Ability to retain } \\
\text { long-term } \\
\text { population with } \\
\text { the subsidies and } \\
\text { tourism income }\end{array}$ \\
\hline $\begin{array}{l}\text { Medium/ } \\
\text { High }\end{array}$ & Low & High & High & $\begin{array}{l}\text { Suburban landscape of high } \\
\text { environmental quality. } \\
\text { Strong relation of city and } \\
\text { neighbouring villages, controlled } \\
\text { building activities }\end{array}$ & $\begin{array}{l}\text { Strong ability to } \\
\text { retain long-term } \\
\text { population }\end{array}$ \\
\hline $\begin{array}{l}\text { Medium/ } \\
\text { High }\end{array}$ & Low & $\begin{array}{l}\text { Low/ } \\
\text { medium }\end{array}$ & Low & $\begin{array}{l}\text { Suburban landscape consuming its } \\
\text { natural capital and values. } \\
\text { Agglomeration zone, uncontrolled } \\
\text { building }\end{array}$ & $\begin{array}{l}\text { Important to stop } \\
\text { the loss of } \\
\text { ecological values }\end{array}$ \\
\hline Low & Low & Low & Low & $\begin{array}{l}\text { Degraded landscape. } \\
\text { Landscape rehabilitation is needed }\end{array}$ & $\begin{array}{l}\text { Low population } \\
\text { retention } \\
\text { capacity }\end{array}$ \\
\hline
\end{tabular}

Following this model, we have defined characteristic regions in the study areas on the basis of landscape function analysis and estimated the long-term population retention capacity. 
We have chosen two rural regions lying along the western and north-eastern borders of Hungary. Both pilot regions contain backward settlements, suffer from severe depopulation processes, and are peripheries or have peripheral parts.

The micro-region of Csorna is situated in the Small-Plain between the great centres of Gyorr-Moson-Sopron County. The micro-region of Csorna holds most of the settlements of Hanság and Rábaköz (intensive agricultural landscape) together. The wetlands, swamps, and forests of Hanság and the banks and gallery forests of River Rába are of great ecological value and are part of the Fertő-Hanság National Park.

In the micro-region of Gönc, the settlements belong to the most disadvantaged areas of the country. The sample area can be divided into two main parts with different landscape characteristics, the upper valley of the Hernád River and the mountains of Zemplén. The subject area consists of two small towns (Gönc and Abaújszántó) and 30 villages grouped around the towns.

If we consider the natural and economic conditions, we have chosen two characteristically different micro-regions: Gönc lies in one of the most backward regions and Csorna and its surroundings in the second richest region of Hungary. However, Southern Rábaköz can be characterized as an inner periphery with decreasing population.

\section{Results and discussions}

The research results allow a detailed comparison of landscape functions between the pilot regions and a sub-regional analysis as well (Figure 1); based on the simplified comparison analysis of landscape functions, we defined the landscape visions.

\section{Results of landscape function analysis}

The ecological indicator shows characteristic differences in both pilot regions. Settlements of Hanság and Tóköz dispose of high natural variety, high rate of seminatural, natural vegetation and protected areas, low or medium intensity of cultivation, diverse land use, small patches of meadows, forest belts and plough fields. Up till the $18^{\text {th }}$ century, Hanság was a vast marshland, but following the drainage works most of the lakes of Hanság and Tóköz disappeared with a few exceptions. The preserved marshlands and lakes are, as strictly protected areas, part of the Fertö-Hanság National Park. Meanwhile, Rábaköz is characterized by a high intensity of agricultural production, which leads to a monotonous landscape with low ecological value. In Rábaköz, the only exceptions are the settlements along 
River Rába, where a narrow belt of gallery forests and meadows provide high biodiversity (Rábasebes).

In the micro-region of Gönc, the Landscape Protection Area of Zemplén, which is one of the most undisturbed and undetected regions in Hungary, has high ecological values, while the agricultural landscape of the Hernád Valley has lower values, where we can witness the lack of the Ecological Network. The lack of the ecological corridors between the core areas (in the mountains and along the river) means that the ecological system cannot work as a real network.

The indicator of landscape aesthetics shows similar values to the indicators of landscape ecology in both pilot regions (Figure 1). In the micro-region of Csorna, the values of naturalness are high in the settlements of Hanság and Tóköz and mostly low in Rábaköz.

In the micro-region of Gönc, the indicator of naturalness shows similar results to the indicator of environmental integrity. The settlements, located in the Mountains of Zemplén, reached high values (e.g. Baskó, Regéc, Mogyoróska, Telkibánya), while the settlements with large cultivated areas have got low values (Felsődobsza, Vizsoly, Vilmány, Pere).

In the micro-region of Csorna, the share of agriculture in economy, employment, and land use is above the national average. Rábaköz is characterized by intensive agriculture. The ratio of plough-lands is extremely high in the microregion (national average: $48 \%$; local average: $66 \%$, with great local differences). Hanság and Tóköz are characterized by low and medium intensity of agriculture. Fruit production is not characteristic either, but there are a few large plantations. Forestry is not important in the region. Most of the forests are situated in the marshland of Hanság (high values of indicator in Csorna) or along the River Rába (Vág, Páli).

Based on the indicator of agricultural potential, we can also divide Gönc micro-region into two significantly different parts. In the Valley of Hernád, the ratio of arable land is very high. This region was historically called as the "pantry of Kosice"; so, agriculture has a great tradition here. Meanwhile, the settlements in the Mountains of Zemplén have very small agricultural areas due to the huge forests. The southern settlements of the micro-region belong to the "Tokaj Wine Region Historic Cultural Landscape" World Heritage Site. The other interesting area is Gönc and the settlements in its surroundings, which are traditionally fruit production areas ("pálinka of Gönc").

In Gönc micro-region, the result of forestry indicator is more or less the inverse of the indicator of arable land potential results. The settlements situated in the Mountains of Zemplén reached a high value of forestry potential. In their economy, forestry has an important role. 


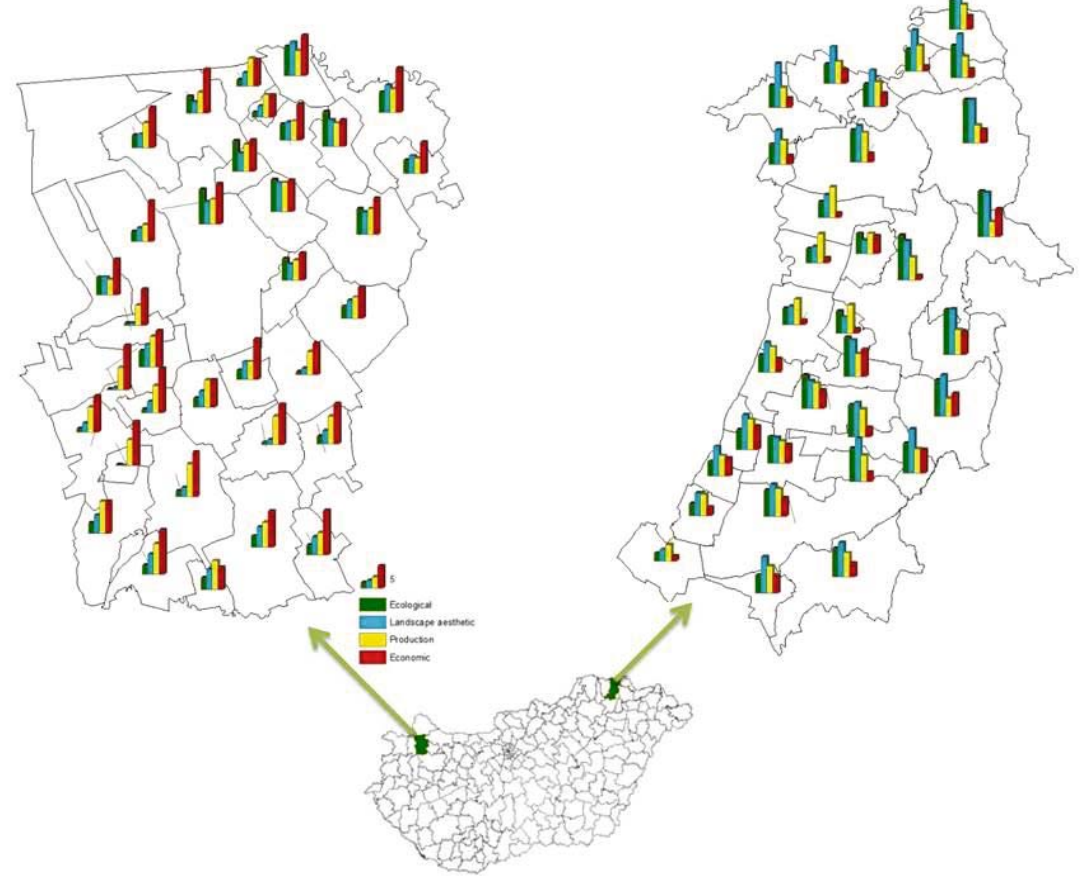

Figure 1. Level of the four value groups regarding the settlements of micro-regions Csorna and Gönc (green - ecological indicator, blue - landscape aesthetics, yellow agricultural production, red - economy)

Figure 1 also highlights the unfavourable economic situation of most of the settlements in the micro-region of Gönc and in the southern settlements of Rábaköz. In micro-region Csorna, the city of Csorna, Bősárkány, Győrsövényház, Kóny, Bősárkány, and Szilsákány have the highest values of the economic indicator. From the point of economic development, the northern part of the microregion can also be divided into two parts. The settlements of Tóköz neighbouring Csorna have unfavourable values. In the eastern part of Tóköz, in the vicinity of the county seat, the settlements are popular and developing. In micro-region Gönc, the settlements in the Mountains of Zemplén have got relatively high values of the indicator. The economy of these villages is mainly based on tourism, wine production, and forestry. In general, the smaller villages in the Valley of Hernád have got the biggest economic and - related to this - social problems.

Summarizing the results of landscape function analysis, we can see that the functioning of several landscape services is insufficient in Rábaköz: the level of 
economic, biotope, cultural, and aesthetic functions are below the optimum. High values can be mostly found just in the settlements of Eastern Tóköz and Hanságmente.

\section{"Landscape visions" in the pilot regions}

The relation between ecological and economic aspects, especially the harmony between them, is extremely important in the sustainable development of rural regions. We consider agricultural production also important because it is one of the most important human activities which transform nature, and it reflects developed or less developed techniques and processes, while it also needs investments in materials and energy. The productive system significantly influences landscape aesthetics. Based on the ecological, economic, and production performances of the pilot regions, we looked for the model scenarios (Table 1). We found several landscape types in the pilot regions (Figure 2).

\section{The micro-region of Csorna}

- Tóköz 1, Hanságmente: Suburban landscape of high environmental quality Settlements of favourable economic situation with high natural value and less intensive agricultural production (good availability) belong to this group.

With the current trends, the maintenance of the present level of population retention capacity is possible in the long run, population growth is expected.

- Tóköz 2: Landscape of traditional, environmentally friendly, agricultural production of low intensity

Settlements of unfavourable economic situation with high natural value and less intensive agricultural production (poor availability) belong to this group.

According to the current trends, population retention capacity cannot be maintained, population loss is expected. Reversal of the current trends is possible by strengthening the central (service, supplying, job-creating) functions of Csorna (agglomeration character, suburban landscape) or by converting limitations into advantages promoting ecological farming, ecotourism reaching the "nature park" character.

\section{- Rábaköz 1: Intensive agricultural landscape (weak multifunctional character)}

Settlements of relatively favourable economic situation, primarily agricultural character with significant industrial, commercial activity and medium ecological value belong to this group. With the current trends, the maintenance of the present level of population retention capacity is possible in the long run; the favourable processes can be strengthened by promoting multifunctional agricultural production and food processing. 


\section{- Rábaköz 2: Intensive agricultural landscape}

Settlements of agricultural character in unfavourable economic situation belong to this group. The current trends cause population loss. The unfavourable trends can be moderated by strengthening the central (service, supplying, job-creating) functions of local centres and promoting multifunctional agricultural production and food processing in the region. Furthermore, the ecological development of the region is inevitable.

- Rábaköz 3: Landscape of traditional, environmental friendly, agricultural production of low intensity

Settlements of unfavourable economic situation with high natural value (Vág, Rábasebes) belong to this group. According to the current trends, population retention capacity cannot be maintained, population loss is expected; the unfavourable processes can be moderated by improving availability and promoting multifunctional agricultural production and ecotourism.
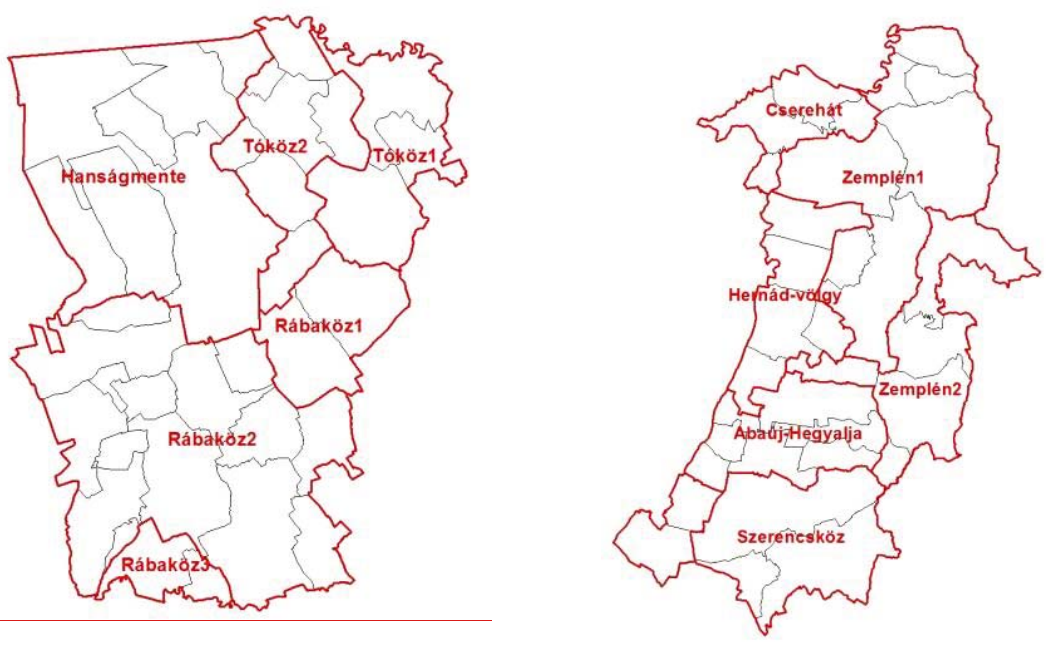

Figure 2. Landscape types in the pilot regions

The micro-region of Gönc

- Cserehát: Basically, industrial agricultural landscape and partly natural values consuming suburban landscape features

Agricultural settlements with low economic and ecological value but with good accessibility belong to this group. Mining is important in the region (gravel mines 
along the river). Landscape aesthetic value is relatively high because of the seminatural Hernád River. Population retention capacity is average (locally low employment needs, but good availability). The population can be sustainable, but more attention will have to be paid to ecological values.

- Zemplén 1: Multifunctional cultural landscape with tourism and traditional, environment-friendly agriculture and forestry

Settlements of average or poor economic situation and of high ecological and landscape aesthetic values (Zemplén Mountains, Landscape Protected Area of Zemplén), settlements of average or rather high production value belong to this group. Forestry and labour-intensive fruit production are important in the region.

The long-term population retention capacity is high (high labour demand in the environmentally friendly agriculture, fruit production). Favourable processes can be fostered by the further development of tourism.

- Hernád Valley: Industrial agricultural landscape

Settlements of agricultural character in unfavourable economic situation belong to this group. Population retention capacity is low (low labour demand); the current trends could be changed by switching the industrial agriculture to a more sustainable and multifunctional way of production (environmentally friendly agriculture, organic farming, landscape management in flood-plain areas). The River Hernád also meant a very good basis for tourism (further development is recommended).

- Zemplén 2: "Naturpark" scenario (tourism and forestry, high number of natural and cultural values)

Settlements in good economic condition with high ecological and landscape aesthetic values belong to this group. Cultivation is of medium intensity, based on forestry, almost no agriculture, with the exception of the gardens and small orchards around the villages. Population is decreasing because of poor availability. Thanks to the natural resources, this trend could be turned back by further development of (nature-based) tourism and clustering, sustainable forestry, high labour demand, handicrafts and food productions (honey, marmalade, etc.).

- Abaúj-Hegyalja: Multifunctional cultural landscape with some traditional, environmentally friendly agricultural features

Settlements of high level of ecological and landscape aesthetic values (Zemplén Mountains; cultural scenic values) with high cultivation intensity (orchards, high percent of arable lands) belong to this group. The economic value is average or below average because of the low profitability of the present agriculture.

Unfavourable processes can be changed by promoting labour-intensive organic farming, fruit production, and development of availability. 
- Szerencsköz: Multifunctional cultural landscape with some natural values consuming suburban landscape features

Settlements with average level of ecological and landscape aesthetic values belong here - production value is high (wine production, Tokaj Wine Region UNESCO World Heritage). The relative good availability and profitability of wine production ensures average economic conditions. For maintaining the relatively good population retention capacity, more attention will have to be paid to environment protection (especially regarding mining). Besides, we recommend a more effective utilization of cultural values and tourism development based on traditional (labourintensive) viticulture.

As Figure 2 shows, we can find almost all scenario models in both pilot regions, with the exception of degraded landscapes. In the micro-region of Gönc, there are several types of landscapes with positive population development trends (multifunctional landscape, nature park); meanwhile, in Csorna, we have found just suburban landscapes with high natural values. In both pilot regions, there are landscape types causing negative population trends: industrial agricultural landscape and landscape of traditional, environmentally friendly, agricultural production of low intensity.

\section{Conclusions}

Despite the different economic situations of the pilot regions, we have found similar correlations between landscape functions and the population retention capacity of the landscape. Sometimes we cannot find clearly the presented scenario models, as our pilot regions also show it. However, we can adjust the state of rural regions to these models which can help to detect the cause and driving forces of negative trends, and within the frames of rural development we can take effective steps to stop them.

The land use system of a rural region can maintain the population retention capacity in the long run in case it can ensure the ecological, economic, and social aspects so that a balanced functioning of landscape functions is favourable. We have witnessed low population retention capacity in the case of high production value with low economic, ecological, and aesthetic values (Hernád Valley, Rábaköz). The "industrial," monotonous agricultural production does not offer appropriate economic base for rural regions because of the lack of labour-intensive production types, products of low level of processing, limited scale of complementary activities, etc. The diversification of the structure of agricultural production could enhance population retention capacity in the pilot regions. 
Multifunctional cultural landscape with diverse production structure could be the priority of rural development for these regions.

In the case of low economic but high ecological and aesthetic value, which characterizes landscapes of traditional, environment-friendly, and agricultural production of low intensity, the model of "nature park" can show the priorities of rural development: promoting ecological farming, ecotourism.

In landscape evaluation, by the application of indicators, we can usually highlight just a small fraction of the complexity of the landscape. For a more detailed analysis or for correction, it is possible to involve a wider range of indicators. In scenario analysis, the relative state of the regions and the determining trends are important. The method is applicable especially to rural developments to formulate visions of the landscape and to highlight the possible negative trends. Such analyses can help to develop effective rural development and landscape management programmes in order to reach positive visions. Further researches for other pilot areas in Hungary and international comparative analysis in other countries enable the improvement and refinement of the method.

\section{References}

[1] Bastian, O., Krönert, R., and Lipský, Z. (2006), Landscape diagnosis on different space and time scales - A challenge for landscape planning. Landscape Ecology 21(3), 359-374.

[2] de Groot, R., Hein, L. (2007), Concept and valuation of landscape functions at different scales. In: Mander, Ü., Wiggering, H., Helming, K. (eds), Multifunctional land use. Berlin/Heidelberg/ New York: Springer, 15-36.

[3] Willemen, L., Hein, L., van Mensvoort, M. E. F.; Verburg, P. H. (2010), Space for people, plants, and livestock? Quantifying interactions among multiple landscape functions in a Dutch rural region. Ecological Indicators 10, 62-73.

[4] Costanza, R., Arge d', R., Groot de, R., Farber, S., Grasso, M., Hannon, B., Limburg, K., Naeem, S., O’Neill, R. V., Paruelo, J., Raskin, R. G., Sutton, P., Belt van den, M. (1997), The value of the world's ecosystem services and natural capital. Nature 387, 253-260.

[5] de Groot, R. S. (1992), Functions of nature: Evaluation of nature in environmental planning, management and decision making. Wolters-Noordhoff, Groningen.

[6] de Groot, R. (2006), Function-analysis and valuation as a tool to assess land use conflicts in planning for sustainable, multi-functional landscapes. Landscape and Urban Planning 75, 175 186.

[7] MEA (Millennium Ecosystem Assessment) (2005), Ecosystems and human well-being: Biodiversity synthesis. World Resource Institute, Washington D.C.

[8] Bastian, O. (1997), Gedanken zur Bewertung von Landschaftsfunktionen - unter besonderer Berücksichtigung der Habitatfunktion, Schnevedingen, Germany: Alfred Toepfer Akademie für Naturschutz.

[9] OECD (2007), OECD Regions at a Glance: 2007 Edition. OECD Publishing, Paris.

[10] Gómez-Sal A., Belmontes J.-A., Nicolau J.-M. (2003), Assessing landscape values: a proposal for a multidimensional conceptual model. Ecological modelling 168, 319-341. 
[11] Koschke, L., Fürst, C., Frank, S., Makeschin, F. (2012), A multi-criteria approach for an integrated land-cover-based assessment of ecosystem services provision to support landscape planning. Ecological Indicators 21, 54-66.

[12] Kollányi L. (2004), Táji indikátorok alkalmazási lehetőségei a környezetállapot értékeléséhez. BKAE Tájtervezési és Területfejlesztési Tanszék, Budapest.

[13] Daniel, T. C. (2001), Whiter scenic beauty? Visual landscape quality assessment in the $21^{\text {st }}$ century. Landscape and Urban Planning 54, 267-282.

[14] Ehrlich, P. R., and Ehrlich, A. H. (1981), Interaction among landscape elements: A core of landscape ecology. New York: Random House.

[15] Swanwick, C. (2002), Landscape character assessment. Guidance for England and Scotland. Scottish Natural Heritage and Countryside Agency, Cheltenham and Edinburgh.

[16] de Groot, R. S., Wilson, M., Boumans, R. (2002), A typology for the description, classification and valuation of ecosystem functions. Goods Services Econ. 41(3), 393-408.

[17] Gobster, P. H. (1999), An ecological aesthetic for forest landscape management. Landscape Journal 18(1), 54-64. 